\title{
Abbreviation Used by Indonesian K-Pop Fans on Twitter
}

\section{Euis Meinawati, Maylinda Vina Violita, Octa Pratama Putra, Herlin Widasiwi Setianingrum, Sufi Alawiyah, Chodidjah}

\author{
Universitas Bina Sarana Informatika Jakarta ${ }^{1-6}$, Indonesia \\ Correspondence: Euis Meinawati, Universitas Bina Sarana Informatika Jakarta; Indonesia. Email: \\ euis.eum@bsi.ac.id
}

Submitted: January 10, 2021

Revised: March 22, 2021

Accepted: March 28, 2021

DOI: 10.29408/veles.v5i1.3060

URL: http://dx.doi.org/10.29408/veles. v5i1.3060

\begin{abstract}
The purpose of the study was to get in depth information of abbreviation usage in Twitter application. The abbreviations were used to make shorter time in delivering a message and the receiver can understand it. The research method was descriptive qualitative. The data were taken from www.twitter.com as an online application that was made by university students, high school students and employees. The study found that 4-fout types of abbreviations have used in twitter communication, namely clipping, blending, acronym, and initial. The abbreviation usage helps people make simple conversations as in non-formal communication.
\end{abstract}

Keywords: abbreviation, k-pop, twitter

\section{Introduction}

Language has an important role in a communication process, because it is the most complete and effective way for someone to convey ideas, messages, intentions, feelings and opinions to others. Everyone should be able to use language, so he or she can give and take information, send their vital messages, and convey the message (Meinawati, 2017). Language use is not just about how to produce language. The sender and receiver have to understand clearly their topic when they are talking.

Nowadays, communication occurs easily in the world. One means is social media. The use of this technology has helped human activity that is easier. People like to communicate by the social network because it is fun, easy to access, is faster, and connect people from around the world. Social media such as Facebook has not only been used for socialization, but also for learning (Meinawati \& Baron, 2019; Moghavvemi, Sulaiman, Jaafar, \& Kasem, 2018). It affect the students' behavior (Kaya \& Bicen, 2016).

A social media is an online platform which uses to create social networks or relations with other people who share similar personal, career interests, activities, backgrounds or real-life connections (Akram \& Kumar, 2017). One of the social media named "Twitter". People can 
spread the information through the post or they called it to tweet on Twitter about what they are thinking, doing, listening, looking for and many more. Users can see what the other share and give a response on it if they also have a Twitter account. This activity created an indirect social interaction. Twitter users in Indonesia were dominated by teenagers, especially K-pop fans.

$\mathrm{K}$-pop is Korean pop or Korean popular music from South Korea. It is a combination of pop culture with Korean lyrics so it makes a new music genre, namely Korean Pop or K-pop. Also, it has unique characteristics. K-pop fans all over the world are massive including in Indonesia, they have a different social background with different habit and behavior and bring their own culture and special characteristic that creates a variety of language. It creates kind of language differently such in phonology, morphology, syntax, and lexicon but still has a structure as the system of language that every speaker knows and understand. Most of the Twitter users are $\mathrm{K}$-pop fans and they rule most of every trending topic on this application. They communicate with each other a lot and also use many language phenomena. One of the language phenomena is the use of abbreviation during the application of social media. The use of abbreviations on Twitter makes it easy for users. They don't spend much time sending messages and don't take long to type in text. Also, they are also easy to remember. However, it might be a little strange for others who are not familiar with English abbreviations.

Deliani (2018) explains the similarities and differences in the use of acronyms and abbreviations in Indonesian. The results of the study concluded that the use of abbreviations or acronyms in Indonesian often combines the initial letters of each word. Another study concluded that in the political rubric of the Kompas newspaper, the use of abbreviations has experienced many shifts for the types of abbreviations initial and blends (Paramitha \& Marlina, 2017). Acronyms included in morphological studies (Alawad, 2018). Abbreviation gives an impact on writing communication (Mokhsin, Aziz, Hamidi, Lokman, \& Halim, 2015). It means that abbreviations used by Indonesian have implemented in communication.

Currently study focuses on abbreviations used by Indonesian K-pop fans in Twitter. The current phenomenon of using abbreviations has become an interesting subject to research, because the delivery of messages through social media such as Twitter using abbreviations can be understood and conveyed to listeners well. This condition seems to have become common place in communication. Even if it is understood that a good communication process, the same understanding occurs in the message communicated.

Therefore, the study formulates the problem as "what is types of abbreviations that used by Indonesian K-Pop fans on Twitter? The purpose of this study is to show the reader about the language phenomenon which happen in social media. It describes the abbreviation used by Kpop fans on Twitter. This research can help the reader to improve their knowledge about morphology especially abbreviations. It gives additional knowledge to the Indonesian K-Pop fans on Twitter that nowadays there are so many abbreviations used in social media. 


\section{Method}

This study used descriptive qualitative. Qualitative research covers a wide range of approaches for the exploration of "human experience, perceptions, motivations and behaviors" and is concerned with the collection and analysis of words whether in the form of speech or writing (Clissett, 2008). The data is taken from www.twitter.com as an online application. The source of data was the Twitter application that has made by university students, high school students and employee. The Twitter application is from online friends on Twitter mostly. 50\% is university students, $20 \%$ is high school students, and $30 \%$ is a different employee. They are around 50 Twitter users.

The procedure of the study has some steps. It is the observation that observed the data on Twitter as the field of research. During the observation, the researcher took note which important thing to be noted. The writer quoted the posts of Indonesian K-Pop fans Twitter users which appear while the researcher doing observation by online. The writer selects fifty posts from 50 Twitter users which consist of English abbreviation and then the writer analyzes the type of the abbreviation. This data collected based on the results of observations from 50 Twitter users who have posted and have abbreviations and have different abbreviations from the sentences which have been posted. After that, the writer seeks theory by reading books, journals, or related research. The writer collects the theories obtained to be understood and compares them with other theories, that the writer can use the most appropriate theory for research.

\section{Results and Discussion}

The result of data analysis concluded that there are four types of abbreviations on Twitter. It describes as the result of data analysis.

\section{A. Clipping}

\section{Data 1 Ult}

Ult is the short term for Ultimate. It essentially means the most favourite or the top person/group they like. K-pop fans usually have one favourite person or group. For example, @wooizhin: "Changmin sih tp ult aku skrg sunwoo," it means the top or the most favourite idol, this user likes is Sunwoo.

\section{Data 2 Nder}

Nder is a short term of Sender, someone that posts a tweet or sent a mention confess anonymously. It is a common thing in Indonesia such as a nickname for them. For example, @ 1obeuforall: "Hrus beli dlu nder...", this user called someone "nder" because someone was sent an anonymous post.

\section{Data 3 Rep}

Rep is short term of Reply. K-pop fans use it, because it is faster and easier to type. 


\section{Data 4 Ava}

Ava is short of avatar. It is a profile picture or image that used to identify the users and tie to their Twitter account. K-pop fans usually use their favorite idol for their avatar.

\section{Data 5 Priv Acc}

Priv Acc is a short term of Private Account. It is an account where all posts on its profile are private or protected, and only approved followers can see posts. The purpose is if they want to be more private and have several close friends. For example, @bucinnya_uyonn: "dor! lewat gakk moots??? kalau lewat, ada yang mau aku angkut ke priv acc aku gak? baru netas soalnya kalau mau like ajaa yaaw, tp yang gak masalah akunnya isinya campur aduk." This user asked her mutual followers whether anyone wants to be her friend on the private account or not.

\section{Data 6 K-pop}

K-pop is a short term of Korean Pop, it is a musical genre originating in South Korea. A group from South Korea called K-pop Idol, and someone who likes K-pop genre called K-pop fans or K-popers.

\section{B. Blending}

\section{Data 1 Fandom}

Fandom is a blend of words of fan and kingdom. In Cambridge dictionary, Fan is a person who adores and interested in something. Meanwhile, the kingdom means territory area. So it means a fan territory area or a group of fans of someone or something, especially very enthusiastic ones.

Fandom can be used for any group. However, over time, the term is very popular and has become a hallmark in the K-pop world. Every K-pop idol group and soloist has a fandom's name. For example, @svnnary_ said ARMY BEST FANDOM, means the fandom name is ARMY.

\section{Data 2 Mulfan}

Mulfan stands for multifandom. It refers to someone who likes more than one of the groups. Usually, K-pop fans feel the struggle when they become a multifandom, because sometimes their favourite groups appear at the same time but it is different occasion or they feel attacked, it's not in a negative way if their favourite idols appear in a short distance of time. For example, @amoreatnic "Belum napas fangirling bangtan ini seungwoo udah update sesuatu aja, beginilah nasib mulfan:')," it is kind of hard to keep up with all of the updates from their favorite idol, but they still enjoy it.

\section{Data 3 Moots}

Moots is a short term for mutual followers, referring to individuals who follow and regularly engage with each other on social media. It is often widely discovered in their singular form, moot. People active in social media also regard their moots as friends of the internet. For 
example, @jodohsnoopy: “Merry Christmas buat moots acuu yang merayakan.” This user said Merry Christmas to her mutual followers or friends online.

\section{Data 4 Menfess}

Menfess is a term combination of two phrases mention and confess. Essentially, it involves mentioning someone (on social media), confessing something to them and doing it all anonymously. It is not always a confession, it can be a message or even a question. If there is a Twitter user provides "auto-menfess", this user is called fan base. They provide some kind of service to anonymously post or tweet the users menfess, for example, this picture below is a base that provides an auto mention confess.

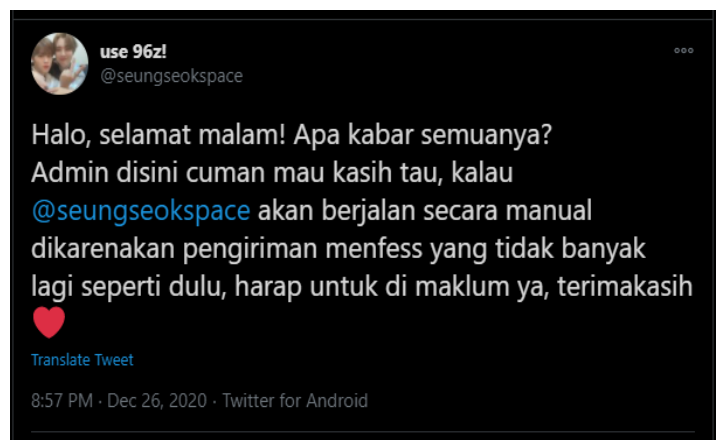

Figure 1. Tweet about menfess

\section{Data 5 Selca}

Selca is a combination of Self and Camera. It means (to take) a picture of yourself, also known as the selfie. It is a slang word from Korea. There is a selca day in the K-pop community, it is a certain day of a month where fans take selfies/selcas and put it sides by side with their favourite idols photo, also most of the fans comes up with a unique concept. The date of selca days is different for every fandom.

\section{Data 6 Opfoll}

Opfoll is Open Follow back. Usually, fan base, big or famous account followed by many users, it does the open follow back so they become a mutual or following each other. Sometimes, open follow back has few terms and rules such as promote or share their account. For example, this picture below shows a fan base asked their followers to create pantun, so they will get a follow back.

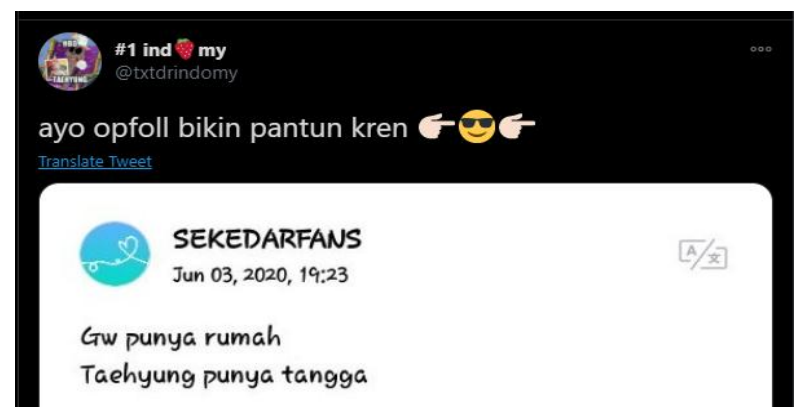

Figure 2. Tweet about Opfoll 
The data above included types of abbreviations blending because blending is a morphological process in which the parts of two or more words are combined to form a new word.

\section{Acronym}

\section{Data 1 BUB}

BUB is an acronym of Block-Unblock. Block is a feature that can be used by users, so another cannot see or access their profile anymore. Meanwhile, unblock is a feature that makes other can see our profile again. K-pop fans do it to cut the friendship without noticed by another user, so they are not following each other anymore. For example, twilightsparqle: "aku stan BTS, X1, SNSD. kalau mau bub silahkan. JANGAN unfoll. BUB aja. jangan nambahin kerjaan." It means, she wanted to cut the friendship because some of her friends dislike her for being that groups' fan.

The writer only found one data for acronyms. The data above included types of abbreviations acronyms because based on the theories, acronyms is a word-formation with the initial letters or each of the major parts of a word or a longer phrase.

\section{Initialism}

\section{Data 1 PC}

PC stands for Photo Card. K-pop album included the artist photo card. PC is probably the most popular piece of merchandise among the K-pop fans, it is also the most common item that can be founded as a part of collections released by the artist. Collecting photo cards is a common hobby for fans, they are eager to complete their collection composed of either a single favourite member's photos or full sets of PC from a different album. They also trade their photo card with other fans to get their favourite idol or to complete the collection. For example, @ibuibuyakult' tweet: "btw ada yang mau trade ngga? sama pc manapun, aku dapet double hiung hiung", it means that user wanted to trade because she got double same photo card.

\section{Data 2 RNB}

RNB is Report and Block. If users see something that violates the Twitter rules, they can report it. Reporting helps signal to twitter party that is going on, and it helps twitter keep conversations healthier in the long term. Twitter users can take action on individual tweets or post, direct message, or accounts.

K-pop fans on Twitter use this feature to report the haters' malicious post towards their favourite idol or fandom. The fandom will write the haters' account username without tagging them because it makes them more famous, so it just reports, then block it. For example, (ayougyulatte: "guys boleh minta tolong buat rnb?? tadi kita honey10 udh baik2 ngedm dia buat takedown tweetnya tapi tiba2 malah close dm. ketikannya jahat bgt dr kemaren soalnya. makasih semuanya!!" This user was asking for help to everyone to report and block a hater's tweet that attacks her fandom. 


\section{Data 3 RL}

RL stands for Real Life. Most of K-pop fans on Twitter do not use their own identity for their account and RL is usually used when they talk about their real-life or business beside of a fan's life. For example, @seokjinii04: “Malam guys? Maaf ya gak bisa interaksi seperti biasanya. Aku lagi sibuk bgt di rl. Kalian jgn lupa jaga kesehatan ya!," this user said that her real life was busy so she cannot interact with her online friends.

\section{Data 4 AU}

AU stands for Alternate Universe. It is a setting for a fan fiction work that departs from the fictional universe canon in which the fan work. There are so many creative K-pop fans that created their own alternate universe on twitter, some of them also became a famous author.

\section{Data 5 OTP}

OTP is short of One True Pairing. It signifies a person's favorite fictional romantic relationship. Fans ship their favorite idol because of their perfect chemistry and fans are, really ship. For example, this user below ships Korean idol Kai and Krystal.

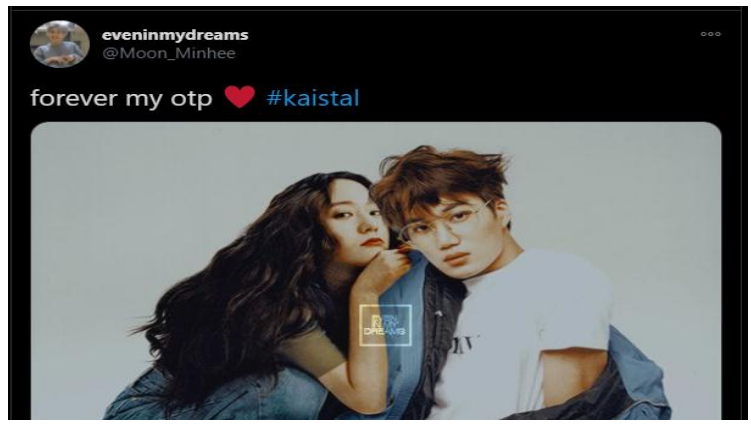

Figure 3. Tweet about OTP

\section{Data 6 RPS}

RPS stands for Real Person Slash. It's a fan fiction term, it means the characters are based on real people and they are paired with the same sex. Slash is a subgenre of fan fiction involving male/male pairings. The word derives from the classic Star Trek fandom; early fans who shipped Kirk and Spock stylized, which contributed to the entire genre being named slash. And there are some of K-pop fan that made a fan fiction with this genre like in this picture below.

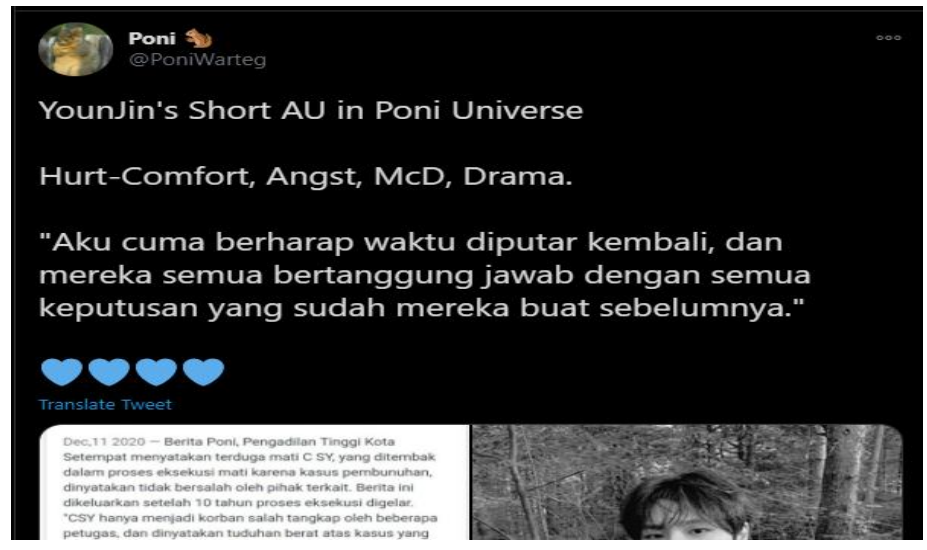

Figure 4. Tweet about RPS 


\section{Data 7 OP}

OP means Original Poster. When someone posts the information and a discussion breaks out in the comments, people refer to the person who posted as "OP".

\section{Data 8 OOMF}

OOMF stands for One of My followers. It is referred to user whom followed you on the social network twitter without revealing their identity. This term used by K-pop fans and most of Twitter user.

\section{Data 9 GDM}

GDM is Group Direct Message. It is a group private messaging feature. Twitter users start a private direct conversation with a group of up to 20 users.

\section{Data 10 WTT}

WTT means Want to Trade. It means that the user is looking to trade one item for another. It is part of the K-pop's culture and a lot of fans are doing it to get the photo card of their favorite idol. For example in this picture, the user lists the photo card and the photo card they want.

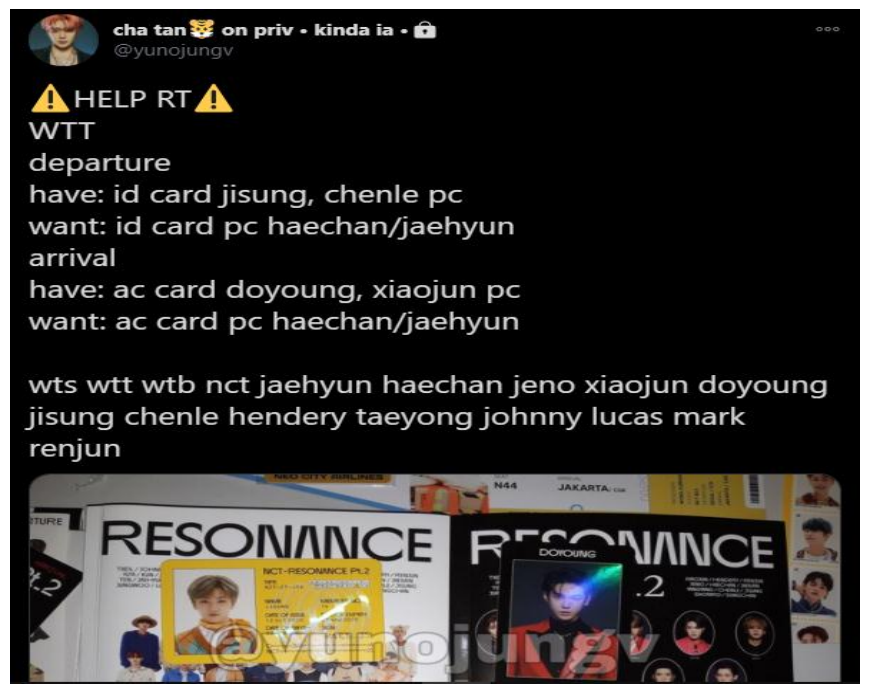

Figure 5. Tweet about WTT

\section{Data 11 OOT}

OOT is short of Out of Topic. If a user describes something that someone says or writes as off-topic, it means that it is not relevant to the current discussion; it used for discussions on the internet.

\section{Data 12 TMI}

TMI stands for Too Much Information. TMI in Korean has different contexts. It means no one would care but you still let them know. People use this word when they talk about themselves and you do not care about it. But a lot of fans would ask their idol what is their TMI for today, so it becomes like a mini trivia for the fans. For example, @toscaminty: "Mau tmi sedikit, sebenernya au ini udah pernah di post sampe 131 diakun kosongan karena akunnya mau 
di alih fungsikan maka dari itu aku pindahkan kesini," it means that it is not important, but this user still wanted to share it though no one cares.

\section{Data 13 FA}

FA is short of Fan Account. It is an account dedicated for fans, post and talked about their favorite idol or group. Fan account does not use their own identity; they will use their idol's picture and create a unique nickname. And sometimes they never talked about their personal life.

\section{Data 14 PA}

PA is short of Personal Account. In this account, the user post about their personal reallife and no K-Pop related. A personal account is used by an individual that person's own needs. It is a relative term to differentiate them from those accounts for fan's related.

\section{Data 15 CB}

CB is short from the comeback. It means a K-pop group returning with new songs. It's the equivalent of saying that a group is releasing a new album, but K-pop fans say that a band is having a comeback instead.

The study discovered 4 kinds of abbreviations that Indonesian K-pop fans often use. There is an initialism with 15 words, another type is blending and clipping which has 6 words each of it, and there is only one acronym. The functions of abbreviations used by K-pop fans are to make short and practice the way of delivering ideas and meaning to other fans, because a tweet has a limited character. Also, abbreviations are very useful for this situation to minimize the space that is given to the reader or users to clarify the words.

In this modern era, technology and social media influence the human's life. The use of abbreviations becomes more significant. People want to discuss many things in more practice way and short in delivering ideas and meaning. Including K-pop fans, it is very useful for them. But, the receiver can get the meaning's speaker. There is a limit on Twitter. As simple as it is, people have started abbreviating words because of a limited number of characters permitted in a single post or tweet. A tweet is only able to contain up to 280 characters or Unicode glyphs, then abbreviations are useful for this situation to minimize the space that is given to the reader or users to clarify the words. Also, the function of the abbreviation for K-pop fans is to make every word shorter and easier to memorize, and it makes a more efficient way of communication by shortening word or phrase.

Most of K-pop fans on Twitter are teenagers, they also use abbreviations to follow and create a modern trend. Then, their shorthand communication can be compared to a specific secret language code between users in various online chats, social media, and instant messaging services like Twitter. This abbreviation code is also an excellent way to secure one-to-one conversations from interference by others. Also, usually, K-pop fans use abbreviations to hide their private chats from non-fans. Besides, some people used Twitter to make non-formal communication such as slang (Izazi \& Tengku-Sepora, 2020). It means there are the process of word-formation in social media communication (Mustafa, Kandasamy, \& Yasin, 2015). It is not only for communication, but also learning process using facebook (Ponnudurai \& Jacob, 2014). 
Therefore, some people can implement the pragmatic function to communicate in social media (Khalifa, 2015). Learning of pragmatic that related with the word formation is in the morphology field, such as derivational, inflection, affixation using song (Aprianti \& Parmawati, 2020; Siboro \& Bram, 2020; Meinawati \& Alawiyah, 2018). This study related with the concept of pragmatic function in understanding of abbreviation too. Like as in this study, the finding show how the user deliver the message using variation of abbreviation and the process of communication can be understood between user. Nowadays, social networking is be as media of communication (Thurairaj, Hoon, Roy, \& Fong, 2015). It also gave the positive and negative impact on society life (Akram \& Kumar, 2017; Arrastia-Chisholm \& Tackett, 2020). Therefore, social media should be a platform of engagement behavior in context (Shahbaznezhad, Dolan, \& Rashidirad, 2021; Heflin, Shewmaker, \& Nguyen, 2017). Also, the social media gave the network complex in creating dynamic environment for society (Martín-Rojas, García-Morales, Garrido-Moreno, \& Salmador-Sánchez, 2020).

\section{Conclusion}

The writer concludes that language and human beings as language users can never be one without another since language and individuals complement each other. The phenomenon of using the English abbreviation can easily be found in the people daily activities, especially in social network activities like Twitter. This study can give deeply information on how to use abbreviation in communication. This study found 4 types of abbreviations, namely 1) clipping is forming mechanism in which a word is reduced to a shorter form. 2) Blending is a morphological process in which the parts of two or more words are combined to form a new word. 3) Acronym is a word-formation with the initial letters or each of the major parts of a word or a longer phrase and 4) initialism is a word-formation that gives the name for something that is still pronounced separately.

The writer suggests the reader who wants to know more details about abbreviations used by K-pop fans on Twitter. For someone who wants to take the final test, the writer wants to suggest it is better to take linguistics and discuss morphology because there are so many morphological processes to be discussed. For someone who wants to take this paper, the writer suggests it is recommended to discuss abbreviations used by Indonesian K-pop fans on Twitter to know more about the types and function of abbreviations used by fans. For the next researcher, the writer suggests taking discussion that is easy, fun and challenging to be analyzed. Do not try discussing that seems too complicated, researchers can explore more theory again to get the best analysis.

\section{Acknowledgments}

Thank you are conveyed to all friends who have joined Twitter as a source of data in research, for friends who have helped the discussion in the data analysis process and the reference sources used for citations. 


\section{References}

akram, w., \& kumar, r. (2017). a study on positive and negative effects of social media on society. international journal of computer sciences and engineering, 5(10), 351-354. https://doi.org/10.26438/ijcse/v5i10.351354

alawad, m. s. a. (2018). exploring the concept of acronyms form a morphological viewpoint. international journal of humanities social sciences and education (ijhsse), 5(1), 1-5.

aprianti, i. n., \& parmawati, a. (2020). derivational and inflectional morpheme analysis on the song lyrics of lady gaga "a star is born" album. project (professional journal of english education), 3(3), 322. https://doi.org/10.22460/project.v3i3.p322-328

arrastia-chisholm, m. c., \& tackett, s. (2020). apps for behavior management, communication, and learning: using sociocultural theory to understand mobile technology in pk-12 settings. peabody journal of education, 95(2), 148-159. https://doi.org/10.1080/0161956x.2020.1745614

clissett, p. (2008). evaluating qualitative research. journal of orthopaedic nursing, 12, 99-105. https://doi.org/10.1016/j.joon.2008.07.009

deliani, s. (2018). the similarities and differences between acronyms and abbreviations in indonesian language. iosr journal of humanities and social science (iosr-jhss), 23(7), 11-16.

heflin, h., shewmaker, j., \& nguyen, j. (2017). impact of mobile technology on student attitudes, engagement, and learning. computers \& education, 107, 91-99. https://doi.org/10.1016/j.compedu.2017.01.006

izazi, z. z., \& tengku-sepora, t. m. (2020). slangs on social media: variations among malay language users on twitter. social sciences \& humanities 2, 28(1), 17-34.

kaya, t., \& bicen, h. (2016). the effects of social media on students' behaviors; facebook as a case study. computers in human behavior, 59, 374-379.

khalifa, r. m. (2015). pragmatic functions of social networks' acronyms. international journal of english language and linguistics research, 3(4), 37-49.

martín-rojas, r., garcía-morales, v. j., garrido-moreno, a., \& salmador-sánchez, m. p. (2020). social media use and the challenge of complexity: evidence from the technology sector. journal of business research. https://doi.org/10.1016/j.jbusres.2019.12.026

meinawati, e.-. (2017). social dimension of slang word in film "animal kingdom." wanastra: jurnal bahasa dan sastra, 9(2), 156-166. https://doi.org/10.31294/w.v9i2.2583

meinawati, e., \& alawiyah, s. (2018). affixation in the script song lyric "hall of fame." research and innovation in language learning, 1(2), 89. https://doi.org/10.33603/rill.v1i2.1108

meinawati, e., \& baron, r. (2019). media sosial dan pembelajaran: studi efektivitas penggunaan facebook dalam pembelajaran bahasa inggris. jurnal tatsqif, 17(1), 34-51. https://doi.org/10.20414/jtq.v17i1.679

moghavvemi, s., sulaiman, a., jaafar, n. i., \& kasem, n. (2018). social media as a complementary learning tool for teaching and learning: the case of youtube. the international journal of management education, 16(1), 37-42. https://doi.org/10.1016/j.ijme.2017.12.001

mokhsin, m., aziz, a. a., hamidi, s. r., lokman, a. m., \& halim, h. a. (2015). impact of using 
abbreviation and homophone words in social networking amongst malaysian youth. advanced science letters, $x(\mathrm{xxx}-\mathrm{xxx}), 1-6$.

mustafa, s. z. b., kandasamy, m. d., \& yasin, m. s. m. (2015). an analysis of word formation process in everyday communication on facebook. international journal of education and research, 3(6), 261-274.

paramitha, a., \& marlina, 1. (2017). types of abbreviation used in instagram. e-journal of english language \& literature, 6(2), 140-148.

ponnudurai, p., \& jacob, t. t. (2014). facebook: a shift from social to academia. procedia - social and behavioral sciences, 123, 122-129. https://doi.org/10.1016/j.sbspro.2014.01.1405

shahbaznezhad, h., dolan, r., \& rashidirad, m. (2021). the role of social media content format and platform in users' engagement behavior. journal of interactive marketing, 53, 47-65. https://doi.org/10.1016/j.intmar.2020.05.001

siboro, e., \& bram, b. (2020). morphological analysis of derivational affixes in brothers grimm's the story of rapunzel. english franca : academic journal of english language and education, 4(1), 71. https://doi.org/10.29240/ef.v4i1.1475

thurairaj, s., hoon, e. p., roy, s. s., \& fong, p. w. (2015). reflections of students' language usage in social networking sites: making or marring academic english. Electronic Journal of ELearning, 13(4), 302-315. 